\title{
Erratum to: Ethics, Diversity Management, and Financial Reporting Quality
}

\author{
Réal Labelle \\ Rim Makni Gargouri \\ Claude Francoeur
}

\section{Erratum to: J Bus Ethics \\ DOI 10.1007/s10551-009-0225-7}

In the above-mentioned article an error was overlooked by the authors during proofreading.

The word 'negative' was used where it should read 'positive'.

Page 1, line 14 of the abstract should read:

'As expected, a positive relation between corporate DM development and financial reporting quality is found while controlling for other factors known in the literatures on governance and accounting choices to affect earnings quality.'

Réal Labelle and Claude Francoeur HEC Montréal, Bureau 5.365, 3000, chemin de la Côte-SainteCatherine, Montréal, QC H3T 2A7, Canada E-mail: claude.francoeur@hec.ca

Rim Makni Gargouri FSEG Sfax, Sfax, Tunisia 